\title{
紙パルプ液の輸送配管における圧力損失計算ソフト*
}

\section{株式会社キッツ 営業技術部齋藤茂 \\ Introduction of Calculation Soft for Pressure Dropping in the Transportation Piping of Liquid Pulp}

Sigeru Saito

Engineering Dept, KITZ Corporation

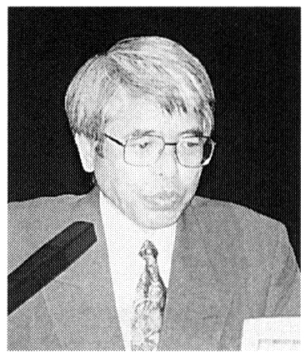

Generally speaking, the pressure dropping degree of pulp liquid depends upon the nominal size of piping and concentration, speed and freeness of the liquid.

On the equipment designing, the calculation of pressure dropping is one of the most important things in selections of pump and nominal size of piping and control valves, however, as indicated in the Figure 1, it seems very difficult to calculate manually in each case.

Upon the requests from our customers and under the above situation, we have developed the unique calculation soft with our own invention, in order to realize an easy calculation by the personal computer.

It has already been introduced for some particular customers, but we, hereby, would like to make it open for all customers. We are very pleased, if this soft could be useful for you.

分類: $\mathrm{J}_{4}$ 移送, $\mathrm{L}_{1}$ 紙料処理 $\cdot$ 調成一般

1.はじめに

パルプ液は濃度，流速，フリーネスおよび配管の口 径などによって圧力損失が異なると言われている。

図 1 はパルプ液 ( $\mathrm{L}$ パルプ) の濃度と流速抢よび配 管口径と配管の圧力損失係数との関倸を参考までに表 したものである。装置設計において, 配管の川径選定, ポンプの選定および調節弁の口径選定では配管の圧力 損失を求めることは欠かせないことの一つだが, 図 1 で示したようにその都度マニュアルにて計算すること は，容易なことではないと考えられる。

このような背景から, 各ユーザーの皆様からのニー

*平成 13 年度年次大会講演（講演 No. A 10）
ズなどもあり，圧力損失の計算を容易にできる工夫を 模索し，コンピュータにて計算できるように，ソフト を開発したので, 紹介するすが, 一部のユーザーの方々 には既に紹介済である。このソフトが少しでも皆様の お役に立てば幸いと思う。

\section{2. ソフトの概要}

配管には抵抗係数の異なるバルブ, エルボ, レジュ 一サ，ストレーナなど流が接続されて扔り，且つサイ ズも異なったものも取付けられている。

ここで紹介するソフトは，このような配管条件にお いても容易に計算できるようにプログラミングされて いる。また，調節弁が接続されている場合は，その調 節弁のコントロール差压も算出できるようにし, ポン 

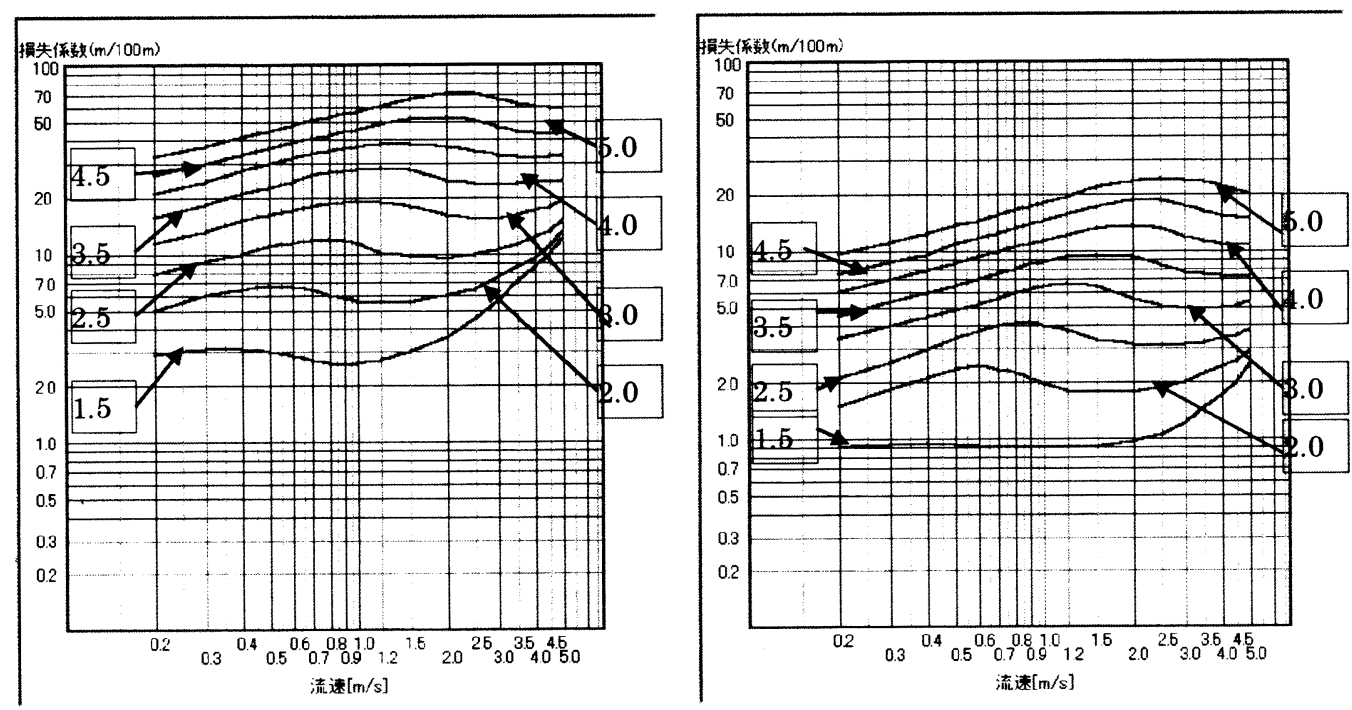

図 1 パルプ液（L パルプ）の濃度と流速および配管口径と配管の圧力損失係数との関係

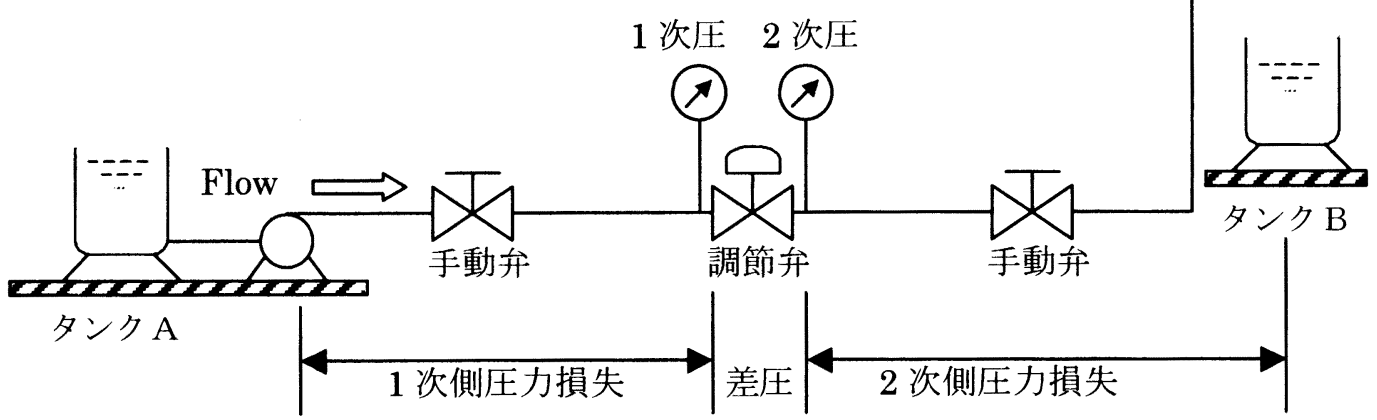

図 2 配管図

プの流量特性を入力すれば，コントロール弁，配管な どを含んだ実行特性も容易にシミュレーションするこ とができる。以下に，このソフトで計算できる内容に ついて説明致する。

\section{3. 圧力損失計算について}

例えば図 2 において，下記仕様の配管の圧力損失と 調節弁の差圧を求める場合を想定し，マニュアル計算 と自動計算の違いについて説明する。

\section{1 配管仕様}

1）流体仕様

流量： $100 \mathrm{~m}^{3} / \mathrm{h}$ および $40 \mathrm{~m}^{3} / \mathrm{h}$

流体名：パルプ液（3\%）

ポンプ吐出圧： $700 \mathrm{kPa}(\mathrm{G})$ から $300 \mathrm{kPa}(\mathrm{G})$

2) 調節弁一次側仕様
配管仕様：サイズ $80 \mathrm{~A}$ ，長さ $30 \mathrm{~m}$ サイズ $100 \mathrm{~A}$, 長さ $100 \mathrm{~m}$

手動弁：チャッキ弁 $80 \mathrm{~A} 2$ 個, ボール弁 $100 \mathrm{~A} 3$ 個 エルボ：溶接形ロング $100 \mathrm{~A} 5$ 個 レジューサ：80 A×100 A 2 組

3) 調節弁 2 次側仕様

配管仕様：サイズ $100 \mathrm{~A}$ ，長さ $50 \mathrm{~m}$ サイズ $125 \mathrm{~A}$ ，長さ $130 \mathrm{~m}$

手動弁：ゲート弁 100 A 5 個, ボール弁 125 A 3 個 エルボ：溶接形ロング $125 \mathrm{~A} 8$ 個 レジューサ：100 A×125 A 3 組

\section{2 計算項目}

(1)各配管サイズ毎の内径における各流量の流体の平 均流速。

(2)各配管サイズ毎のパルプ液濃度における各流量の 
$100 \mathrm{~m}$ あたりの損失水頭。

(3)各配管の長さに対する圧力損失。

(4)各バルブおよび各サイズ毎の各流量に対する圧力 損失。

(5)各エルボのサイズ毎および各流量の圧力損失。 (6)各レジューサのサイズ毎および各流量の圧力損失。 (7)調節弁の 1 次側と 2 次側毎の压力損失。

(8)コトロールする各流量のポンプの吐出圧力。

(9)以上を全て計算した上で，最後に調節弁で消費さ せる差圧（余㮃エネルギ）の計算。

\section{3 マニュアル計算}

(1)マニュアル計算を行うためには配管，エルボ，レ ジューサなどのスケジュールによって異なる管の 内径，バルブデータ ( $\mathrm{CV}$ 值または相当管長)，パ ルプ液の濃度毎の損失データなどを事前に用意し ておく。

(2)計算に必要な計算式および計算方法を確認する。

(3)計算を行うためにはその計算方法を熟知していな ければならないため，それなりのスキルが必要。

(4)前述の計算項目を全て計算する。

(5)計算仕様に一部変更が生じた場合，変更内容によ っては再度初めから計算をし直さなければならな w。

(6)計算結果を確認するためには, 最低でも2 回程度 は同じ計算を繰り返す必要がある。このように， マニュアルにて計算する場合は多くの手間と時間 が掛かりまた，計算仕様の一部変更が生じた場合， 変更内容によっては再度初めから計算をし直さな ければならない。

\section{4 ソフトによる自動計算}

(1)計算を行うための配管やそれに取付けられる種々 のデータを事前に用意する必要がない。（必要な データは子めデータファイルを用意してある。)

(2)計算に必要な計算式および計算方法は予めプログ ラミングされている。

(3)計算を実行するためのスキルは不要である。 (4)前述の計算項目は全てコンピュータが実行する。

(5)計算するデータは流量, 温度ポンプデータ, 配管 の長さ以外は殆んど表示されたリストからマウス でクリックして選択する方法ですので，データの 入力ミスも少なくて済み, デー夕の入力時間を大 幅に短縮できる。

(6)一度使用した配管などの入力デー夕は自動的に登 録されますので，プログラム終了後，新たに計算 データの変更が生じても, 変更が容易にでき瞬時 に再計算を実行することが可能である。

\section{4. データの入力画面}

\section{1 計算データの入力画面}

図 3 に計算データの入力画面を示す。

4.2 バルブデータの入力画面

図 4 にバルブデータの入力画面を示す。

4.3 レジューサデータの入力画面

図 5 にレジューサデータの入力画面を示す。

4.4 エルボデータの入力画面

図 6 にエルボデータの入力画面を示す。

4.5 配管データの入力画面

図 7 に配管デー夕の人力画面を示す。

\section{6 計算結果の表示画面}

図8に計算結果の表示画面を示す。

\begin{tabular}{|c|c|c|c|}
\hline \multicolumn{2}{|c|}{ 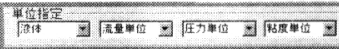 } & \multicolumn{2}{|c|}{ 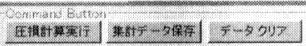 } \\
\hline 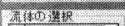 & 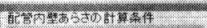 & & 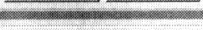 \\
\hline खita & 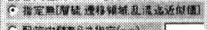 & 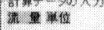 & III If $(0)$ I \\
\hline 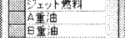 & 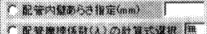 & E为䧳 & 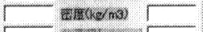 \\
\hline 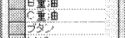 & 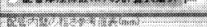 & *fo of & 2द्या: \\
\hline 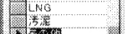 & & 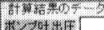 & 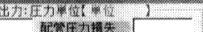 \\
\hline $\begin{array}{ll}20 \\
20 \pi\end{array}$ & & 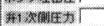 & 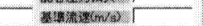 \\
\hline & & 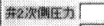 & 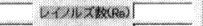 \\
\hline sats $=2 x$ & & 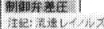 & 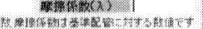 \\
\hline
\end{tabular}

図 3 計算データの入力画面

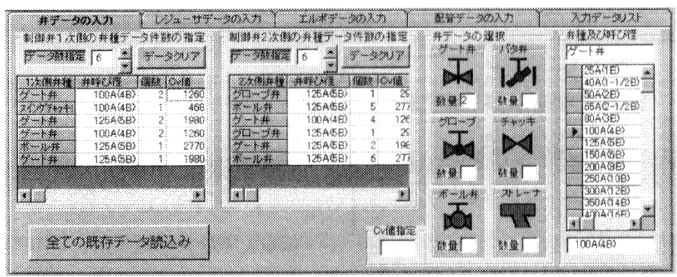

図 4 バルブデータの人力画面

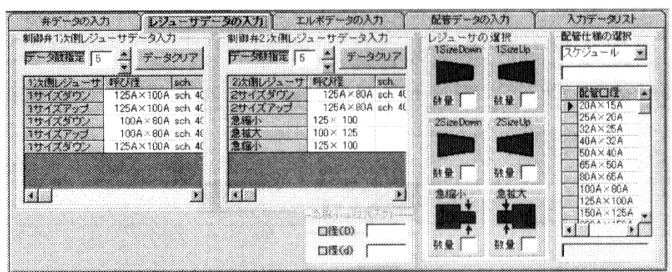

図 5 レジューサデータの入力两面

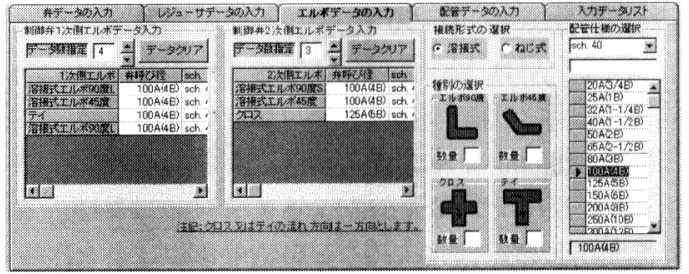

図 6 エルボデータの入力画面 


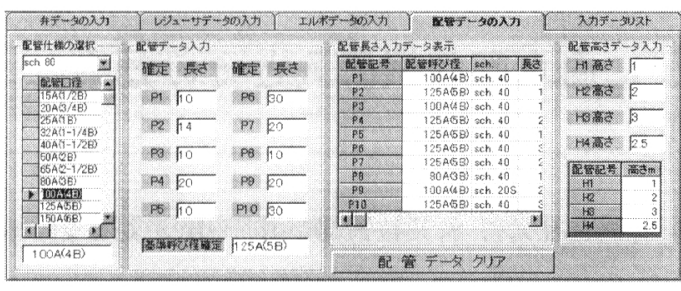

図 7 配管データの入力画面

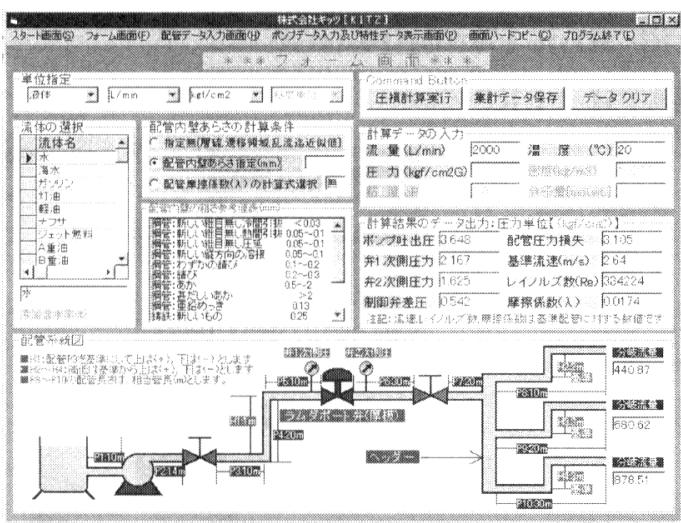

図 8 計算結果の表示画面

\section{5. コントロールバルブの実行特性}

図 2 のコントルールバルブの実行特性は, バルブの 固有特性，ポンプの流量特性および配管系の総抵抗に よって変化する。

例えばバルブの固有特性およびポンプの流量特性を 図9のようなものとすればその実行特性はある条件下 に拈いては図10のように変化する。

仮にマニュアルによって計算すると，前述で示した 計算を少なくても弁開度 $5 \%$ 毎に行わなくてはなら ないので，およそ20回程度は計算を繰り返す必要が ある。このような計算掞いては，多大な時間をかけて も満足な答えが得られない場合もあり徒労に終わるこ とも覚悟しなければならない。

例えばコンピュータを使用したとき，流体が水の場 合 1 回の計算時間が約 5 秒以下，パルプ液の場合でも 20 秒以下程度で計算可能である（但し，コンピュー タのプロセッサー $300 \mathrm{MHz}$ 程度以上として)。従って, 短時間にていろいろな弁種および弁口径に対してシミ ユレーションを行うことが可能なる。

6. その他の下記の計算ソフトおよびデータ

(1)弁の容量計算 ( $\mathrm{CV}$ 值) および調節弁の口径サイ ジング

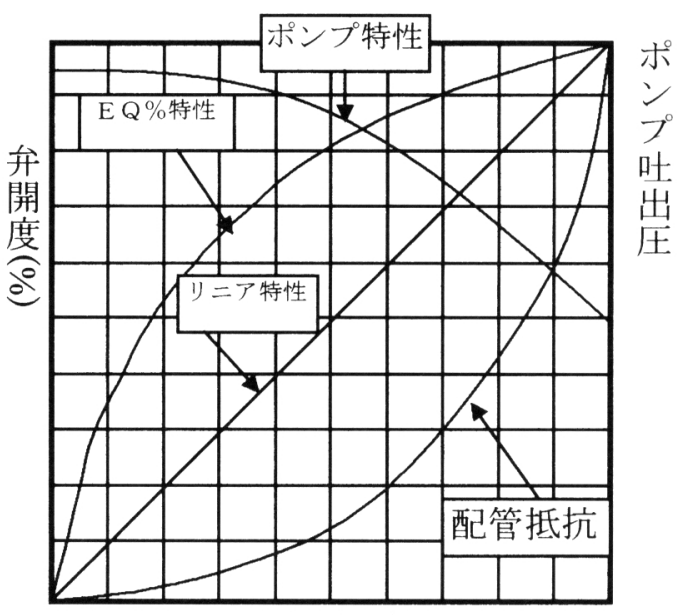

流量 $(\%)$

図 9 バルブの固有特性とポンプの流量特性

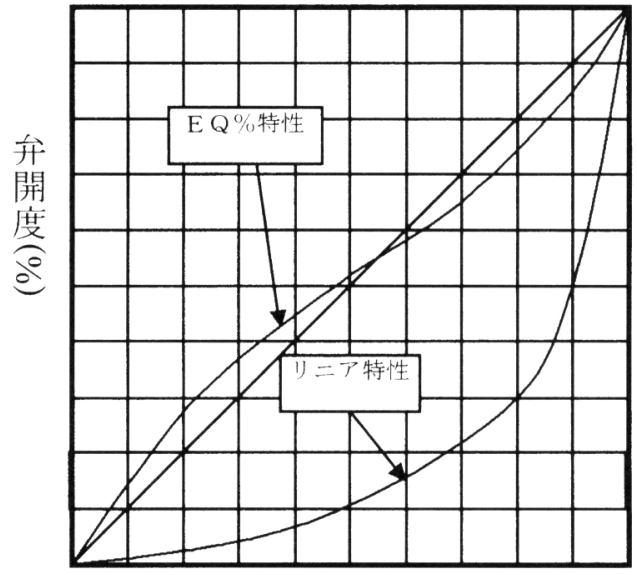

流量 $(\%)$

図 10 尘行特性

(2)ウータハンマの昇压および衝撃力の計算

(3)JIS Z 8762 に準拠したオリフィス計算（流量計算, オリフィス孔径計算，差圧計算など）

(4)単位換算ソフト（バルブ関連で使用される単位： 13 種類の単位換算)

(5)化学薬品とバルブ材料の耐食データ

(6)バルブの規格毎の肉厚データ

(7)バルブの圧力・温度レーティングデータおよびそ の補間計算ソフト

8)バルブの規格毎による弁座の許容漏れ量データと その計算ソフト

(9) 自由落下による, タンクからの流出流量およびそ の時間の計算など 